\title{
Developing Blended Learning Model GAWI SABUMI Based on Ecopedagogy Study to Improve Ecological Awareness and Industrial Revolution 4.0 Skills on Elementary Education
}

\author{
Noorhapizah $^{1^{*}}$ Akhmad Riandy $^{1}$ Diani Ayu Pratiwi ${ }^{1}$ \\ ${ }^{1}$ Elementary School Teacher Education, FKIP, Lambung Mangkurat University, Indonesia \\ ${ }^{*}$ Corresponding author.Email: noorhapizah@ulm.ac.id
}

\begin{abstract}
This research will show about (1) the characteristics and implementation of blended learning model GAWI SABUMI; (2) The appropriateness of implementation blended learning model GAWI SABUMI; (3) the effectiveness of implementation blended learning model GAWI SABUMI to improve soft and social skills pass COVID-19 pandemic. The method of this research uses Research and Development (R\&D) with the Four-D model (definition, design, development, and dissemination). The sample of this research is 45 person elementary school students on Banjarmasin. Collecting data use observation, documentation, interview, test, and questionnaire. Observation is used to know the effectiveness of implementation blended learning model, the improvement of ecological awareness, critical thinking, problem-solving and independence, collaboration, negotiation and analytical thinking. Documentation is used to collect every document along with the implementation of this model. The interview is used to know the effectiveness of this model from the teacher and student side. The test is used to know the improvement of critical thinking and problem-solving skills. The last, questionnaire is used to know the effectiveness of the implementation of a blended learning model GAWI SABUMI to improve soft and social skills. Data analysis uses the Interactive Model from Miles and Huberman. The indicator of this research improvement of revolution 4.0 skills included: critical thinking, problem-solving, analytical thinking, collaboration and negotiation. The result shows that (1) the characteristic and implementation of the blended learning model GAWI SABUMI consist of Group, Analysis, Work Together, Inform, Solve the problem on outdoor, Actualization of solution, Battle games, Unity on role play, Manage conclusion and Invent the creation; (2) blended learning model GAWI SABUMI is appropriate to be used according to the results of the validation from 3 experts with validation percentage of learning model $91 \%$, skills development $84,56 \%$ and learning media $86 \%$. (3) blended learning model GAWI SABUMI is effective to be used in learning based on the results of evaluations using instruments of soft and social skills. The improvement after implementation blended learning model, the students who are getting high criteria on ecological awareness increase to $81,3 \%$, critical thinking increase to $85,6 \%$, problem-solving increase to $75,6 \%$, analytical thinking increase to $81,4 \%$, collaboration increase to $77,6 \%$, independence increase to $77,2 \%$ and negotiation increase to $80,6 \%$. The conclusion is blended learning model GAWI SABUMI can improve students' industrial revolution 4.0 skills.
\end{abstract}

Keywords: Blended learning, ecopedagogy, ecological awareness, industrial revolution 4.0 skills.

\section{INTRODUCTION}

The learning process in the 21 st century and the 4.0 industrial revolution requires learning activities that lead to the development of critical thinking and creative thinking skills consisting of critical thinking, problem solving, creative thinking, analytical thinking, lifelong learning, independent management, new literacy such as technology literacy. and much more than that, creative thinking, innovation skills, collaboration with others and leadership $[1,2,3,4,5]$. These skills cannot be developed without good collaboration from every stakeholder. Future human resources will face more challenges such as information and technology literacy skills, critical thinking and creative thinking skills, analytical thinking and collaboration (Dhanapal \& Lim, 2014; Suriansyah, 2018). On the other hand, Bialik (2015) states that the main components in $21^{\text {st }}$ century learning are skills, knowledge, metacognition, and character. We must be committed to designing learning activities that develop these skills, so 
that learning outcomes are not only oriented to cognitive skills.

Learning in the $21^{\text {st }}$ century has experienced major obstacles during the Covid-19 pandemic since February 2020. This condition requires elementary school teachers to change the learning paradigm that was initially carried out face-to-face, into online or online-based learning. This learning method should not be an excuse as an obstacle to the development of priority skills to be developed in the current learning process such as ecological awareness, critical thinking, problem-solving and independence, collaboration, negotiation and analytical thinking [6] [7][1][2][3][8].

The skill that must be developed to ensure the lives of future generations is ecological awareness. Ecological awareness must be developed from an early age, the perfect time to cultivate a sense and sensitivity to care for the environment is at the elementary school age. Primary school students as the next generation of life in the future must have the ability to protect and preserve the environment, so that currently learning must contain content on environmental problems and students are expected to be able to provide alternative solutions to problems that occur $[9,10]$. Starting from the findings of a literature review which suggests that currently human knowledge about the need for life between humans and nature, most humans do not have a high awareness of the obligation to strive to maintain balance, harmony and harmony in nature [10] (Gunawan, Darsiharjo \& Somantri, 2017).

In addition, skills development that is demanded by society in the future must be implemented in various conditions and situations. This view is very important in the midst of conditions in this country which must carry out learning from home to prevent the spread of the COVID-19 virus. Learning from home is not a big obstacle to prioritizing the development of higher order thinking skills in elementary school age children. This is based on the important role of higher-order thinking skills to give birth to a productive generation and ensure the progress of this country. A skill that should be developed since elementary school age is critical thinking. If students have these skills, they are able to think deeply and structurally and dare to present the truth and evaluate various things in a multi-perspective way. These skills will help a person make the right and best decisions in life. $[1,12,13,14,3,4,14]$.

A skill that is no less important for future generations to have is critical thinking. A critical person will be able to innovate through the development of broad ideas and put forward new opinions and findings to solve problems in social life, have a high curiosity to seek the truth of an opinion, and even make students able to be open and responsive to different perspectives $[1,3,4,14]$.

Skills that support critical thinking are problem solving. Today's education is required to produce elementary school graduates who are able to think critically. Problem solving skills have an impact on students' ability to think deeply and consider various solutions to problems to produce fast, precise and accurate solutions
$[3,4,5,6,7,8,22,23]$. Students will trained in critical thinking to have speed and accuracy in solving problems and getting used to arguing or communicating with various points of view according to the context of the problem $[9,10,11,12,13,14,15,16,32,33]$.

Skills that support critical and problem solving is analytical thinking. Agusta, Setyosari \& Sa'dijah [6] suggest that analytical thinking activities allow students to have in-depth analysis skills of a case that arises around their lives, then solve it through rational solutions and logically acceptable thinking. With this skill, a person will have an adequate understanding of seeing reality and have a desire to solve problems straightforwardly and precisely. Problem solving abilities are a series of procedures or strategies that allow a person to increase independence in thinking $[15,34,35]$.

A skill that is no less important to instill in the younger generation is collaboration, negotiation and independence, Setyosari (2009) views collaboration as an important element to be developed because it can instill social skills, the ability to respect and be responsible for students. This is in line with Hosnan's (2016:87) statement that the ability to collaborate is a step to develop adaptability, responsibility, productivity, empathy, and mutual respect despite differences in views. Research states that collaboration in groups will result in efficiency and effectiveness in doing various things, that's what West said as quoted by Nurnawati, Yulianti, and Susanto [36]. Research by Manafe, Setyosari, Kuswandi, and Ulfa [37] also puts forward the impact of group collaboration and negotiation on students' technical skills and self-efficacy. A consistent statement is also stated through the research of Mawarni, Soetjipto, and Sa'dijah (2017) that the use of cooperative strategies and independence learning that prioritize collaboration skills and learning independence is able to develop student self-esteem and has an impact on their learning outcomes. The impact of collaboration is also stated in research conducted by Chiu (2004) which reveals that the content of collaboration and negotiation contained in cooperative learning has a positive impact on problem solving skills and the efficiency of task completion time.

However, during the Covid-19 virus pandemic, it was impossible to obtain data through direct interaction with the object of research. This pandemic make the teachers can't improve student critical thinking because can' interact directly with students, they are confuse how to make the strategy to improve students skill without meet directly with students. The same case is happen on improving students' problem solving and analytical thinking. They don't have more strategy to improve soft skills. It makes the learning process is hampered. In other hand, beside the soft skills, we need to improve other industrial revolution 4.0 skills such as Collaboration, negotiation and independence. Teacher feel impossible to improve that skills because of can't meet student directly and they don't have enough strategy to make it happen.

In the midst of the high spread of viruses that can endanger human lives, every level is competing to develop strategies that are able to train students' thinking skills even if it is 
done without face-to-face interaction in the classroom. One of the solutions offered is the development of blended learning with the concept of combining learning with direct interaction with internet media as a link, but modified with elements of developing thinking skills since elementary school age.

Blended Learning is learning that combines direct interaction to transfer knowledge combined with media in the form of interactive CDs and electronic books that are accessed via the internet network [38]. Efforts to use blended learning for the development of learning communities in the network are implemented by various levels of education, which are not only distance education providers (PJJ), but have penetrated the educational community that implements independent learning with various media. They integrate various components of online learning with conventional classrooms $[38,39,40]$.

Researchers suggest that learning is said to be Blended Learning when it combines at least two learning methods aimed at achieving learning demands. Thorne (2003) reveals a condition that can be observed in traditional classrooms that require teachers and students to meet face to face in the transfer of knowledge, but by utilizing an internet network, learning can be done anywhere and anytime not bound by time and distance.

A condition that we often encounter is blended learning based on virtual learning that brings together students and teachers. They can interact even though they are in different places, allowing them to be in tough situations such as during the Covid-19 virus pandemic. Bersin [39] supports this statement through the results of his research which suggests that blended learning is carried out by combining several different methods, both in the form of technology, internet, activities and various situations in order to carry out optimal learning for certain students. Blended learning implies conventional learning combined with electronic facilities and internet networks. This is a learning alternative that can be used to overcome the limitations of direct interaction such as time, distance, and various other situations that prevent conventional learning from running (Isa, 2015; Aly, 2016; Yao; 2016).

Blended learning puts students forward as an important factor who will be given a variety of independent knowledge and give rise to analytical, critical and creative attitudes. Thus, various educational institutions today must be able to create strategies in the form of blended learning that are designed according to student characteristics and skills that will be developed according to community demands [40] (Aly, 2016; Manik \& Lubbers, 2016; Garner $\&$ Rouse, 2016). Based on this background, the researcher seeks to analyze the results of the development of a blended learning model that contains high-level thinking skills within the boundaries of critical thinking, creative thinking and problem solving amid social restrictions and interactions between teachers and elementary school students. The learning model developed is called the GAWI SABUMI blended learning model (Group, Analysis, Work Together, Inform, Solve the problem on outdoor, Invent the Creation, Battle games Unity on role play, Manage conclusion and Invent the creation) The formulation of the problem in this research is How is the application of the blended learning model GAWI SABUMI?. Is the GAWI SABUMI blended learning model effective for improving the higher order thinking skills of elementary school students?

\section{METHOD}

Based on the problems to be resolved, researchers used a research method in the form of research and development (R \& D) proposed by Borg \& Gall. This research will produce innovative products that are different from other products, both modified and new products to support work in the world of education and learning. This product allows the teaching and learning process to be optimal to achieve the expected goals [41].

The steps in the research research and development research method (R \& D) Thiagarajan, Semmel, Semmel (1974) are known as the 4D method (Define, Design, Develop, and Disseminate). The define stage is the stage for determining and defining the terms of learning. The define stage includes five main steps, namely front-end analysis, student analysis (learner analysis), teacher analysis, skill development analysis and formulation of learning objectives (specifying instructional objectives). The design stage aims to design a learning model. Four steps must be taken at this stage, namely: (1) preparation of skills to be developed, (2) preparation of learning steps, (3) examining the meaning and purpose of each learning step. The next stage is develop, this stage will produce a product development which is carried out in two steps, namely: (1) expert appraisal followed by revision, (2) developmental testing. The last process is disseminate, this stage is the final stage of development. The dissemination stage is carried out to promote the development product to be accepted by users, whether individuals, a group, or a system. According to Thiagarajan et al, [42], "the terminal stages of final packaging, diffusion, and adoption are most important although most frequently overlooked.

The define stage was carried out to determine the blended learning model used in several schools in Banjarmasin during the Covid-19 pandemic with the following stages: front-end analysis explores information on the blended learning model used in several elementary schools in Banjarmasin City, the skills developed in the blended learning model that has been used and the development needs of the blended learning model to meet the needs of today's society.

The design stage starts from the preparation of the skills to be developed. This skill arrangement is carried out based on the analysis that has been done previously. After knowing the priority skills to be developed in elementary schools, the researcher arranged the steps for the GAWI SABUMI blended learning model. Each step of the model is analyzed in depth for the substances and skills that can be developed after carrying out these steps.

The next stage is develop, this stage will produce product development which is carried out in two steps, namely expert appraisal followed by revision and developmental testing. Expert assessment is carried out by three people 
who are selected from three points of view, namely experts on learning steps, experts on skills developed and experts in media and technology. Furthermore, a wider model trial was conducted to determine the effectiveness of the model through repeated actions based on the opinion of Hopkins (1993: 121) which includes activities (1) planning strategies for implementing the blended learning model, (2) implementing blended learning, (3) reflection learning outcomes and processes, and (4) observation and improvement of the learning process. The trial process was carried out in four learning meetings, for grade 5 students at SDN Karang Mekar 1 Banjarmasin and SDN Sungai Miai 7 Banjarmasin. The first stage was carried out on grade 5 students at SDN Pasar Lama Banjarmasin with a total of 30 students. the second stage was carried out on grade 5 students of SDN Sungai Miai 7 Banjarmasin with a total of 30 students. So that it is possible for more complete data variation and accuracy to improve the GAWI SABUMI blended learning model so that it is considered effective in developing students' higher-order and social thinking skills.

Product feasibility trials are conducted to determine the feasibility level. Based on the deficiencies in the trial results, the researchers made revisions to the parts that were still inadequate, so as to produce a product that was suitable for use. Product trial designs are carried out to obtain data that will be used to determine product deficiencies that are developed as a basis for revising products [41]. In addition, the purpose of the trial was to determine the feasibility and effectiveness of GAWI SABUMI's blended learning.

Collecting data in this study using observation, documentation, interview, test and questionnaire techniques [41]. Observations are used to determine the effectiveness of using the GAWI SABUMI blended learning model, development of ecological awareness skills in the form of exploring environmental issues, packaging action strategies to overcome environmental issues, skills to act on environmental issues, attitude skills and good personality attitudes. Furthermore, industrial revolution 4.0 in the form of critical thinking skills, problem solving, analytical thinking, independence, collaboration and negotiation. Observation of the effectiveness of learning using the GAWI SABUMI blended learning model uses the teacher activity observation sheet and student activity in each learning step that has been compiled. Observations will also be used to determine the improvement of each skill item based on the grid collected from the opinions of experts. Each student activity will be observed whether they have critical thinking skills, problem solving, independence, collaboration, negotiation and analytical thinking.

Documentation is used to collect documents during the implementation of the GAWI SABUMI blended learning model. Documents collected were notes during the learning process, input and improvements from reviewers, photos and videos during the learning process, student work and products produced during the learning process using the GAWI SABUMI blended learning model
The test technique is used to explore students' abilities in critical thinking, problem solving and analytical thinking. The test instruments used in the form of essays and multiple choice were prepared based on cognitive verbs related to critical thinking skills, critical thinking and problem solving starting from $\mathrm{C} 4$.

The data analysis in this study was carried out qualitatively and quantitatively, regarding the implementation of the learning model. Qualitative analysis is used to describe the results of preliminary research, quantitative analysis related to the implementation and influence of the developed model. Quantitative analysis used statistical analysis [43]. Activities in data analysis include grouping data based on variables and types of respondents, tabulating data based on variables from all respondents, presenting data for each variable studied, performing calculations to answer problem formulations, and performing calculations to test hypotheses that have been proposed.

\section{RESULTS}

Research and development was carried out from April to July 2020 during the Covid-19 pandemic, which required all schools in South Kalimantan to carry out learning from home. The results of this study will be presented in three parts, consisting of the conditions of learning during the Covid-19 pandemic at SDN Karang Mekar 1 Banjarmasin, the development of the GAWI SABUMI blended learning model and the effectiveness of the GAWI SABUMI blended learning model to improve the high-level thinking skills of elementary school student. Learning Conditions during the Covid-19 Pandemic at SDN Karang Mekar 1 Banjarmasin At the beginning of March 2020, the Banjarmasin City government announced a large-scale preparatory period for social restrictions after more than 20 Banjarmasin residents tested positive for the Covid-19 Virus. This condition requires all schools in the city of Banjarmasin to be closed and the teaching and learning process to be shifted from face-to-face to online-based learning.

This condition requires teachers at SDN Karang Mekar 1 Banjarmasin to implement learning from home even though with a simple method, namely using the Whats App application group. The teacher provides learning in the form of voice and video recordings, then accompanied by assignments that must be done by students. However, the collection of product assignments is done by handing them directly to the teacher at the school. This learning method is boring for students after running for one month. In addition, SDN Karang Mekar 1's mission which prioritizes the development of ecological awareness, thinking skills and social skills is not running optimally. Seeing this fact, researchers who are colleagues of teachers at SDN Karang Mekar 1 Banjarmasin are looking for effective ways to develop learning that leads to the development of ecological awareness, soft and social skills even though they have to learn from home.

Development of the GAWI SABUMI Blended Learning Model (Group, Analysis, Work Together, Inform, Solve 
the problem on outdoor, Invent the Creation, Battle games Unity on role play, Manage conclusion and Invent the creation).

\subsection{Define Stage}

The development stage begins with the define stage by collecting information to analyze the needs at SDN Karang Mekar 1. Information is collected through five analysis activities. front-end analysis, learner analysis, teacher analysis, skill development analysis, and (specifying instructional objectives.

Based on the front-end analysis conducted by conducting virtual interviews using the Google Meet application with high-grade teachers at SDN Karang Mekar 1, consisting of 3 class 4 homeroom teachers, 3 class 5 homeroom teachers, 3 class 6 homeroom teachers and the principal. Information was obtained that: (1) teachers find it difficult to interact directly with students to develop critical thinking skills that require teachers to provoke children to ask questions, answer questions orally, provide mutual corrections to friends' answers and provide various answers; (2) learning is very limited to providing material in the form of voice messages and through videos that must be made one day before learning, this will hinder the development of students' abilities to explore problems with teacher directions in depth, providing facts around them which are usually done quickly through direct questioning, distinguishing relevant and less relevant arguments, generating a large number of ideas; (3) learning cannot evaluate the ability of students to argue and express their thoughts, this will hinder the development of skills to think of different ways to solve problems, produce something new from developing existing ideas, develop other people's ideas by providing additional or a stimulus for a simple idea to make it look more attractive, explaining the meaning of a given idea, understanding the problem by describing the problem using one's own language; (4) learning cannot ensure that students explore the environment in ecopedagogy content that is included in learning social knowledge content, as well as various things related to learning topics that are usually directed through seeing directly the object of study in the surrounding environment. This will hinder the development of students' abilities to develop ecological awareness, present problems in detail, have high curiosity by exploring problems through various future-oriented questions, developing problem-solving strategies, finding solutions with various ways of extracting information, solving different problems. from friends, producing alternative solutions to various problems.

\subsection{Design stage}

The second development stage is design creation. The activity begins with planning, at this stage, the researcher does the following: The planning stage in implementing this model takes several activities, including: (1) identifying learning materials, researchers and teachers reviewing the material to be delivered in accordance with the continuity of previous learning ; (2) Designing learning steps using GAWI SABUMI blended learning; (3) Determining the types of network-based learning media, namely interactive learning videos, google meet applications and zoom meetings, ensuring adequate internet networks and determining learning materials. Interactive video media containing material about Humans and the Environment, Environmental Change, Environmental Conservation Efforts that contain problems accompanied by project-based activities in each lesson. (4) making learning tools such as learning implementation plans, teaching materials containing the theme of our Friends Environment (Theme 8 in the 2013 revised 2018 curriculum) which has been modified according to the needs of blended learning, as well as teacher guidelines for implementing the GAWI SABUMI blended learning model. (5) include ecopedagogy content in learning activities. (6) identify the skills developed in each step of the GAWI SABUMI blended learning mode

Furthermore, the researcher developed a preliminary product format (develop a preliminary form of product). Product development begins with determining the substance of the GAWI SABUMI blended learning model. The GAWI SABUMI model is a blended learning model that promotes virtual or online learning but is accompanied by detailed activities to increase children's ecological awareness, soft skills and social skills. The development was continued by designing the GAWI SABUMI blended learning steps which were detailed as follows:

Table 1. The Step of Blended Learning GAWI SABUMI

\begin{tabular}{|c|l|}
\hline $\begin{array}{c}\text { Learning } \\
\text { Step }\end{array}$ & \multicolumn{1}{c|}{ Implementation } \\
\hline Group & $\begin{array}{l}\text { The activity begins with gathering teachers and students in a virtual classroom using Google Meet or } \\
\text { Zoom Meeting. At this meeting, the teacher uses audio to provide a detailed explanation of the } \\
\text { substance of the physical activities that have been carried out. Explanations can be done in person or } \\
\text { using a voice recording. The explanations are supported by videos to provide more concrete knowledge } \\
\text { to students. } \\
\text { The teacher will present as many question and answer activities as possible to give students the } \\
\text { opportunity to answer questions and provide arguments, the teacher will also provide opportunities for } \\
\text { students to provide answers to other students questions so that various answers emerge. }\end{array}$ \\
\hline Analysis, & $\begin{array}{l}\text { The activity was continued by distributing student worksheets that offered several solutions that the } \\
\text { group of students would give. Students will be directed to analyze what will happen if the solution is }\end{array}$ \\
\hline
\end{tabular}




\begin{tabular}{|c|c|}
\hline $\begin{array}{c}\text { Learning } \\
\text { Step }\end{array}$ & Implementation \\
\hline & $\begin{array}{l}\text { pplied. To be more focused, analysis activities are equipped with worksheets that will guide students } \\
\text { express their opinions and reasoning about the solutions given. Each group must organize their } \\
\text { arning experience so that they can find material concepts based on the problems raised by the } \\
\text { acher. Analysis activities will formulate the results of reasoning that will be carried out in physical } \\
\text { ctivity. }\end{array}$ \\
\hline $\begin{array}{c}\text { Work } \\
\text { Together }\end{array}$ & $\begin{array}{l}\text { Students will be divided into several groups consisting of 3-4 people. students will be directed to } \\
\text { negotiate with friends in the group. Negotiation is a continuation of the observing and questioning } \\
\text { activities that have been raised in the Auditory activity. Negotiations started with the teacher } \\
\text { distributing number cards with different problems, the cards were given in the Whats App application } \\
\text { group in the form of pictures. The teacher will place students with the same problem in a group, groups } \\
\text { are formed with a special Whars App group which contains } 3-4 \text { students. The teacher provides } \\
\text { different factual problems for each group so that they will try to analyze each problem presented. } \\
\text { Students will negotiate in groups to formulate in detail what problems are happening, what will happen } \\
\text { if the problems are left alone. }\end{array}$ \\
\hline Inform, & $\begin{array}{l}\text { This activity is certainly inseparable from training students to raise a lot of questions, because the } \\
\text { teacher's explanation will provoke students to express their curiosity about the problems that occur and } \\
\text { provoke students to prepare solutions that will be given. } \\
\text { The teacher will add activities to give students the opportunity to evaluate various ideas given to } \\
\text { distinguish between relevant arguments and irrelevant arguments, until finally giving all students the } \\
\text { opportunity to conclude idea }\end{array}$ \\
\hline $\begin{array}{c}\text { Solve the } \\
\text { problem on } \\
\text { outdoor, }\end{array}$ & $\begin{array}{l}\text { Students will be directed to do physical activities that will train students to test the results of reasoning } \\
\text { about the solutions given with friends in the group. Physical activity consists of exploring things that } \\
\text { can be found in the child's environment. The group will investigate critically, systematically, and } \\
\text { logically so that they can formulate their own findings confidently. Before students do physical } \\
\text { activity, the teacher will provide clear directions starting from the activity steps to the final result that } \\
\text { will be obtained in the form of collecting data through information gathering activities so that their } \\
\text { critical thinking skills will be honed through this activity. }\end{array}$ \\
\hline $\begin{array}{l}\text { Actualizati } \\
\text { on of } \\
\text { solution }\end{array}$ & $\begin{array}{l}\text { The results obtained from physical activity are used to carry out administer information activities using } \\
\text { group worksheets. Group worksheets are distributed through the WhatsApp group, then students who } \\
\text { previously conducted the experiment individually are grouped into groups with the feature of dividing } \\
\text { participants into groups on the Zoom Meeting or google meet application. Another alternative that } \\
\text { teachers can do is to use WhatsApp media by forming small groups. Students will work together to } \\
\text { identify each item of question related to trying / gathering information. Students will administer the } \\
\text { information that has been obtained and hone their knowledge and convey the meaning of the process of } \\
\text { trying / digging up information on physical activities. }\end{array}$ \\
\hline $\begin{array}{l}\text { Battle } \\
\text { games }\end{array}$ & $\begin{array}{l}\text { At the end of the lesson before the teacher gives an award, students are invited to do a game. The game } \\
\text { is designed to be flexible, not bound by rules. The game is intended to provide fun activities for } \\
\text { students even though they are studying online at home. The game is designed to give students the } \\
\text { opportunity to interact with each other, either by using the WhatsApp, Google Meet or Zoom Meeting } \\
\text { applications. }\end{array}$ \\
\hline $\begin{array}{l}\text { Unity on } \\
\text { role play }\end{array}$ & $\begin{array}{l}\text { This activity is filled with illustrating events related to subject matter that involve students as the main } \\
\text { actors in it. The delivery of illustrations is done in the form of a story as well as provoke enthusiasm } \\
\text { for students in practical activities through motion and words. The teacher prepares scenarios before the } \\
\text { start of learning to clarify the learning material to be delivered. The teacher prepares a scenario before } \\
\text { the start of learning to clarify the learning material that will be delivered or given to students. The } \\
\text { teacher asks each group representative to come forward to get information on learning materials that } \\
\text { will be delivered by the teacher. }\end{array}$ \\
\hline $\begin{array}{l}\text { Manage } \\
\text { conclusion } \\
\text { and Invent } \\
\quad \text { the } \\
\text { creation }\end{array}$ & $\begin{array}{l}\text { The results obtained from physical activity are used to carry out administer information activities using } \\
\text { group worksheets. Group worksheets are distributed through the WhatsApp group, then students who } \\
\text { previously conducted the experiment individually are grouped into groups with the feature of dividing } \\
\text { participants into groups on the Zoom Meeting or google meet application. Another alternative that } \\
\text { teachers can do is to use WhatsApp media by forming small groups. Students will work together to } \\
\text { identify each item of question related to trying / gathering information }\end{array}$ \\
\hline
\end{tabular}


The blended model step design that has been compiled is then validated by modeling experts, skills development experts and learning device experts with construct validity. Furthermore, the results of the validation of these three experts will show the feasibility level of the GAWI
SABUMI blended learning model which is used as a guide. The recapitulation of the results of the blended learning model validation from three experts can be seen in table 2 .

Table 2 The results of the validation of the GAWI SABUMI blended learning model from experts

\begin{tabular}{|l|l|c|c|}
\hline No. & \multicolumn{1}{|c|}{ Reviewer } & Validation Score & Percentage \\
\hline 1 & Learning model & 4,78 & $91 \%$ \\
\hline 2 & Skill Development & 4,15 & $84,56 \%$ \\
\hline 3 & Learning media & 4,39 & $86 \%$ \\
\hline \multicolumn{2}{|c|}{ Average } & 4,43 & $87,19 \%$ \\
\hline
\end{tabular}

Declared very feasible and usable. Even so, the validator provides comments and suggestions for revising some parts before they are used in learning. Improvements were made by describing in more detail the syntax of the blended learning model which consists of eight syntaxes, namely Group, Analysis, Work Together, Inform, Solve the problem on outdoor, Invent the Creation, Battle games Unity on role play, Manage conclusion and Invent the creation. This shows that the expert gave a positive response by answering with a minimum score of 4 in the 1-5 range on all the proposed assessment items.

Almost every component of the supporting factors received suggestions and input from the validator. These suggestions, among others, need to reconsider between activities and the allocation of learning time. According to experts, learning activities with learning objectives are carried out too much, so that it requires more time allocation. Revisions are made by improving the learning objectives at each meeting so that learning activities do not exceed the specified time allocation. This is in line with the results of research conducted by Mahnun [44] which states that in determining learning objectives, one must pay attention to available time management so that all learning objectives can be achieved optimally.

In addition, according to experts, there are discrepancies between lesson plans and teaching materials. Activities written in the student lesson plans only make study visits. This is because learning visits are carried out outside of lesson hours so that they do not enter into the learning activities written in the lesson plans, but the directions for conducting study visits are explained in the closing lesson lesson plans. Kurnianingtyas (2016) states that study visits are more effective and efficient if they are carried out outside of class hours so that they do not interfere with class hours. Study visits outside of class hours are not limited by lesson hours so that students can explore more knowledge related to burnt batik and can take advantage of study time effectively and efficiently. After the revision was made according to the validation input, it was declared feasible by the three experts, this was because improvements had been made according to the advice of the experts.

The next stage is a small scale trial. Small-scale trials were conducted at SDN Karang Mekar 1 with a total of 15 students. The data obtained from this small-scale trial was in the form of student responses regarding the GAWI
SABUMI blended learning model which consists of eight aspects with 24 statement numbers. Based on student responses to the use of the GAWI SABUMI blended learning model, it shows that the average score of 15 students is $84.5 \%$. These results indicate that the learning model developed is very good for learning. Furthermore, a large-scale trial was carried out using the experimental method. The experimental class and control class chosen were class $5 \mathrm{~A}$ and $5 \mathrm{~B}$. The experimental class consisted of 45 people and the control class had the number of greetings, namely 44 people. Just like a small-scale trial, in the form of student responses to the GAWI SABUMI blended learning model which consists of eight aspects with 24 statement numbers. Based on students' responses to the use of the GAWI SABUMI blended learning model, it shows that the average score of 15 students was $89.4 \%$. In detail, student responses to large-scale trials can be seen in table 3

Students are also trained to have critical thinking, problem-solving and independent skills in learning. This is because the GAWI SABUMI blended learning is specifically designed to include activities that can develop critical thinking skills, problem solving and learning independence. Critical thinking skills are presented by training students to focus questions, analyze arguments, ask and answer about an explanation or challenge, conclude an idea or solution, interpret facts or conclusions or logical statements based on the information provided, evaluate and distinguish between strong arguments and relevant and weak or irrelevant arguments. Problemsolving skills are developed by presenting activities to demonstrate understanding the problem, organizing data and selecting relevant information in problem solving, choosing appropriate problem-solving approaches and methods, developing problem-solving strategies and solving non-routine problems. Learning independence is developed by presenting self-confidence training activities, encouraging students to actively participate in learning, hone student discipline, and consistently practice responsibility in participating in learning. Thus learning activities are designed to help students to actively learn. Other data obtained from large-scale trials, namely the assessment of learning implementation and student learning outcomes. The implementation of the activities of teachers and students in the learning process is presented in Figure 1 : 


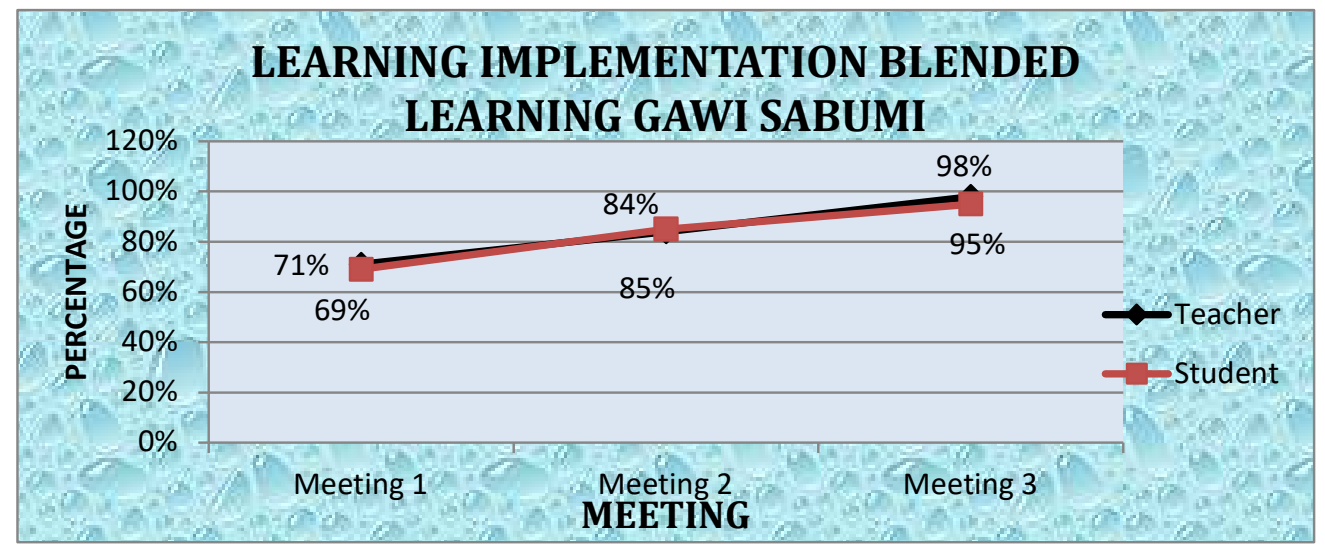

Figure 1 Learning Implementation Blended Learning Model

Overall the teacher can implement learning activities according to plan. Learning is more meaningful because students learn directly from the surrounding environment about topics related to the environment. The entire syntax of the learning model has been implemented according to the expected criteria. The teacher guides students to carry out Group activities, Analysis, Work Together, Inform, Solve the problem on outdoor, Invent the Creation, Battle games Unity on role play, Manage conclusion and Invent the creation. Each activity is carried out by paying attention to the narrative implementation of the specified syntax. This has been prepared in advance by the researcher and the homeroom teacher. Furthermore, the researcher acts as an observer to observe the implementation of each step of the model so that further comments are made if there are mistakes. Based on the results obtained, at the 1st meeting the teacher still had problems in several steps, especially when presenting group learning online. So that it requires researchers to take part in providing direction to students. Especially for the implementation of learning by students, teachers and researchers collaborate to ensure that all students follow each learning step optimally. The direction is carried out by ensuring that students know the tasks in learning activities one by one.

Research in the large-scale trial phase also explores learning outcome data before and after using the GAWI SABUMI blended learning model. In addition to learning outcomes, all skills were also analyzed for improvement using the $\mathrm{N}$-gain analysis to obtain an increase with an average of 0.59 in the "medium" category. The results of $\mathrm{N}$ gain analysis on large-scale trials can be seen in table 3 .

Table $3 \mathrm{~N}$ Gain of Big Scale trial on 3 Meetings

\begin{tabular}{|l|c|c|c|c|c|c|c|c|c|}
\hline \multirow{2}{*}{ Result } & \multicolumn{9}{|c|}{ Kategori N Gain (\%) } \\
\cline { 2 - 11 } & \multicolumn{3}{|c|}{ Meeting 1 } & \multicolumn{3}{c|}{ Meeting 2 } & \multicolumn{3}{c|}{ Meeting 3 } \\
\hline & Low & Middle & High & Low & Middle & High & Low & Middle & High \\
\hline Knowledge & 66,8 & 8,2 & 25 & 19,4 & 49,2 & 31,4 & 12,4 & 3,4 & 84,2 \\
\hline $\begin{array}{l}\text { Ecological } \\
\text { awareness }\end{array}$ & 68,1 & 7,2 & 24,7 & 18,3 & 48,7 & 33 & 14,6 & 4,1 & 81,3 \\
\hline Critical Thinking & 58,6 & 8,8 & 32,6 & 21,2 & 26,7 & 52,1 & 4,4 & 0,0 & 85,6 \\
\hline Problem Solving & 61,2 & 9,4 & 29,4 & 16,3 & 38,4 & 45,3 & 21,2 & 3,2 & 75,6 \\
\hline Analytical Thinking & 69,2 & 6,5 & 24,3 & 21,2 & 48,7 & 30,1 & 16,4 & 2,2 & 81,4 \\
\hline Collaboration & 67,4 & 6,7 & 25,9 & 19,8 & 50,2 & 30 & 20,1 & 2,3 & 77,6 \\
\hline Independence & 52,1 & 8,8 & 39,1 & 15,6 & 46,4 & 38 & 19,8 & 3,0 & 77,2 \\
\hline Negotiation & 67,4 & 9,3 & 23,3 & 22,1 & 45,3 & 32,6 & 15,0 & 4,4 & 80,6 \\
\hline
\end{tabular}

The increase in the value of knowledge is dominated by the "high" category because the learning presented provides very high motivation to students. The learning process is also not dominated by the transfer of knowledge in the form of theory, but students are brought to participate in learning with a variety of collaborative and independent information gathering activities. Students are also led to explore various problems that occur around them, so that they are not required to memorize theories that make learning less meaningful.

A significant increase also occurred in Ecological awareness, in a short time students were able to acquire these skills with intensive guidance from teachers and researchers. Learning is also directed at extracting information on problems that arise in their environment or that are familiar among them. This makes it easy for students to recognize the problems that occur. The activity 
was continued by finding alternative solutions to problems with colleagues in the group. This activity is also designed to be as attractive as possible even though it is only carried out online via the Zoom Meeting page, Google Meet or WhatsApp. This becomes a new routine for students so that it provokes student motivation and has an impact on increasing the quality of learning significantly.

An aspect that is no less important in this research is problem solving which has also increased significantly. This is because all indicators of problem solving skills are discussed one by one and developed for all students through the guidance of teachers and researchers. All students feel challenged to explore the problems that occur and look for alternative solutions to problems with friends in the group. Teachers and researchers give appreciation and reinforcement to students' ability to explore and solve problems, even though the results obtained are not yet perfect. This appreciation and reinforcement from the teacher also provokes student motivation to always try and try without fear of mistakes.

Learning is also directed to grow Independence. This can be seen from the percentage acquisition in the high category which dominates. This is because learning is provided with clear directions and communicative learning resources and contains detailed narrative directions for various activities, making students less dependent on teachers. A very encouraging condition was that at the third meeting the students were exploring alternative solutions to problems that did not require teacher guidance. They are very enthusiastic to argue to contribute ideas to solve the current problem

A significant increase also occurred in the collaboration aspect, almost all students obtained very good criteria. This is because the learning process prioritizes group learning and fosters a collaborative spirit in students. All students are guided not only to share assignments in groups, but to cultivate collaboration values in each student. Students are encouraged intensively to care for each other and have responsibility for group assignments. Students are also given the opportunity to interact and communicate with each other so that the problem solving carried out in the group runs optimally. This activity also fosters negotiation skills. All students are trained to prioritize common interests and prioritize group interests. Coupled with the development of analytical thinking skills both individually and in groups. A learning process like this fosters collaboration, negotiation and analytical thinking skills.

\section{DISCUSSION}

The GAWI SABUMI blended learning model is an idea of overcoming learning problems during the COVID-19 pandemic. Even though the country is still in a state of a virus outbreak, learning in schools cannot be sacrificed. The learning process must continue, either in the form of knowledge transfer or skills development. The GAWI SABUMI blended learning model is an alternative solution for developing student skills even though learning is only carried out from home. This is in line with the results of the research by Noorhapizah, Agusta and Pratiwi (2020) that the learning process must run optimally even though conditions require teachers and students to interact online from their respective homes. The GAWI SABUMI blended learning model is also an alternative solution for developing student skills that teachers can use as a reference, because according to the research of Noorhapizah, Agusta and Pratiwi (2020) most teachers still have not mastered the concept of skills that must be developed in elementary school students and have not been able to package learning loaded with these skills.

The skill that must be developed to ensure the lives of future generations is ecological awareness. Ecological awareness must be developed from an early age, the perfect time to cultivate a sense and sensitivity to care for the environment is at the elementary school age. Primary school students as the next generation of life in the future must have the ability to protect and preserve the environment, so that currently learning must contain content on environmental problems and students are expected to be able to provide alternative solutions to problems that occur $[9,10]$. Starting from the findings of a literature review which suggests that currently human knowledge about the need for life between humans and nature, most humans do not have a high awareness of the obligation to strive to maintain balance, harmony and harmony in nature [10].

In addition, concern for the environment becomes an attitude and character that will encourage humans to strive to prevent and overcome various types of damage to the natural environment, especially the environment around them. They will work together to develop various innovations to regenerate the natural damage that has occurred. To realize this, it is necessary to make efforts to develop environmental awareness in students from an early age through learning that contains environmentbased content or we are known as ecopedagogy. Ecopedagogy will foster a new paradigm in developing awareness of the need to preserve the natural environment through ecopedagogy-based education in instilling ecological awareness and character in the younger generation.

The development of the GAWI SABUMI model is also based on the demand to produce elementary school graduates who are capable of critical thinking. Critical thinking skills have an impact on students' ability to think deeply and consider various solutions to problems to produce fast, precise and accurate solutions $[4,5,6,7,8,9$, $20,22,23]$. Shiva who is accustomed to being trained in critical thinking will have speed and accuracy in solving problems and getting used to arguing or communicating with various points of view according to the context of the problem [10,11,12,13,14,16,32,33].

Critical thinking skills are very important to be developed and integrated in learning. This is in line with the goals of education in elementary schools, namely being able to think critically. But in reality, the implementation of learning in schools tends to pay less attention to critical thinking skills, especially in the midst of the Covid-19 pandemic because teachers and students cannot interact 
directly. Therefore, the learning paradigm should shift from conventional learning which emphasizes low-level thinking skills towards higher-order thinking skills learning, especially critical thinking which is the basis that students must have in order to develop higher-order thinking. Thinking is an active, orderly, and meaningful process by which we understand the world. Critical thinking is thinking to systematically investigate the process of thinking itself, meaning not only thinking on purpose, but also examining how we and others use evidence and logic [12,22,23,24,25,26,27,28, 52,53,54].

Critical thinking is the most important part in the learning process because critical thinking will create a younger generation who are able to interpret, analyze, conclude, evaluate, explain and self-regulate both in education and in the general field [28,29,30,31,32] (Suh, 2010; Ketter, 2014). The importance of critical thinking skills becomes a strong foundation for researchers to package the GAWI SABUMI blended learning model, several learning steps include activities to develop critical thinking skills, namely Auditory, Analysis, and Somatic activities. Apart from focusing on improving critical thinking skills, the development of the GAWI SABUMI blended learning model also has the advantage of increasing student learning independence. Studies in a period of nearly 10 years report that students who have high learning independence show a tendency to learn better under their own supervision than in program supervision, are able to monitor, evaluate, and organize their learning effectively, save time in completing assignments and organize learning and time efficiently $[33,34,61,62,63,64,65,66]$.

Learning independence is one of the skills developed in the 2013 curriculum. The 2013 curriculum not only encourages the development of learning outcomes in the cognitive component, but affective aspects should be developed in students simultaneously and proportionally, one of which is independence in learning. Independent learning does not mean learning alone without the help of others. Some experts define self-regulated learning (abbreviated SRL) in different ways. However, this different definition contains three main steps in SRL, namely: a) designing its own learning according to its objectives, b) choosing a strategy and implementing its learning plan, and c) monitoring its own learning progress, evaluating its learning outcomes and comparing it with certain standards $[34,35,19,36,60,69,70,71,72,73,74]$.

The development of independent learning is intended so that students have the ability to monitor their own behavior to compare their own positions with certain standards and be able to respond themselves to both positive and negative responses. Students who have independence in learning will have intrinsic learning initiative and motivation, have the habit of diagnosing learning needs, are able to set learning goals or targets, monitor, organize, and control learning, view difficulties as challenges, utilize and find relevant sources, choose, apply learning strategies, evaluating learning processes and outcomes $[71,75,76,77,78,79,80,81,82,83,84]$. Thus, the GAWI SABUMI blended learning model contains various learning steps in which it provides independent guidance in learning. The development of independent learning can be found in almost all learning steps, namely Auditory, Negotiation on Themes, Analysis, Somatic, Administer Information, Role Play to Interaction on Games.

This activity will train students to be able to think critically. Activities are designed to develop critical thinking indicators which consist of focusing questions, analyzing arguments, asking and answering questions about an explanation or challenge, concluding an idea or solution, interpreting facts or conclusions or logical statements based on the information provided, evaluating, differentiating between strong and relevant arguments and arguments that are weak or irrelevant $[4,5,6,7,8,12,22,23,25,52,53,54]$. This activity step is in line with previous research which states that critical thinking can be developed by asking questions or giving students the opportunity to make questions from observations $[13,14,27]$, giving students the opportunity to explore the problems that are happening from the observations [17,24], opening students' insights using concrete and various objects $[11,15,16,23]$, using the surrounding environment as an object of observation $[12,22,32]$ involving students providing arguments to answer questions $[21,25,26,85]$.

In addition, the development of GAWI SABUMI blended learning is one of the strategies to train critical thinking using mobile learning technology. This is in line with the results of research showing that using mobile learning can develop students' critical thinking $[10,26,33,86]$, this blended learning model also trains students. to be able to interpret, analyze, conclude, evaluate, explain and selfregulation (self-efficacy) both in the education and general fields [38,29,30,31].

The activity was continued with the Analysis activity. In this activity, the teacher will provide more specific learning content to explore environmental issues associated with the South Kalimantan area. Students will be asked to analyze what will happen if the problem is left alone. Then students and groups will discuss the best solution to the problem being discussed. Furthermore, students will be directed to analyze what will happen if the solution is applied. To be more focused, analysis activities are equipped with worksheets that will guide students to express their opinions and reasoning about the solutions given. Each group must organize their learning experience so that they can find material concepts based on the problems raised by the teacher. Analysis activities will formulate the results of reasoning that will be carried out in physical activity.

Analysis activities will also hone students' analytical thinking skills through giving and receiving information, conveying opinions or arguments within the group, responding to statements from friends in the group during discussions, explaining what will and has been done in the group, receiving information provided by group friends properly and give a positive response even though there are differences of opinion. This activity will also train students' independence in learning in order to grow selfconfidence, be active in learning, discipline and responsibility. Analysis activities will also train students' 
collaboration skills starting from working collaboratively, contributing in groups, conveying information clearly, communicating with each other, caring for all group members, responding to every group need and participating fully in various steps to solve problems. The GAWI SABUMI blended learning step is followed by Work Together and Inform. Students will negotiate with friends in groups. Negotiations started with the teacher distributing number cards with different problems, the cards were given in the Whats App application group in the form of pictures. Students will negotiate in groups to formulate in detail what problems are happening, what will happen if the problems are left alone. Students are given experiences to focus attention on the problem at hand, focus on the interests of finding solutions, gather some information to choose before making a final decision, ensure that the results are based on objective criteria. Students will also be equipped with the skills to contribute in groups and share analytical thinking information.

Negotiation skills can be formed through activities with groups to explore information about problems [88], involving students directly to feel the problems that are happening by sharing information [89], providing opportunities for students to express opinion and test the understanding of each group member with spontaneous questions but give other students the opportunity to help friends who are being asked spontaneous questions [90], give students the opportunity to share their experiences and come up with solutions based on reasoning and think about the impact that will occur if alternative solutions are applied [36], students are given the freedom to explore opinions through group experiments and involve all group members to participate in each other $[1,40]$.

The activity continued with Solve the problem on outdoor. Students will be directed to do physical activities that will train students to test the results of reasoning about the solutions given with friends in the group. Physical activity consists of exploring things that can be found in the child's environment. The group will investigate critically, systematically, and logically so that they can formulate their own findings confidently. The teacher will provide an explanation through the Google Meet or Zoom Meeting application so that all students can listen to detailed directions from the teacher.

This activity is also a continuation of the development of ecological awareness in the form of packaging action strategies to address environmental issues and Implementing solutions. Somatic activities again train problem-solving skills that focus on data organizing skills and selecting relevant information in problem solving, implementing appropriate problem-solving approaches and methods.

Somatic activities will also hone students' analytical thinking skills through giving and receiving information, conveying opinions or arguments in the group, responding to statements from friends in the group during discussions, explaining what will and has been done in the group, accepting information provided by group friends properly and give a positive response despite differences of opinion. The activity was continued with Actualization of Solution.
Students will work together to identify each item of question related to trying/gathering information. Students will administer the information that has been obtained and hone knowledge and convey the meaning of the process of trying / digging up information on physical activity.

This activity will also train students' independence in learning in order to grow self-confidence, be active in learning, discipline and responsibility. Administer information activities will also train students' collaboration skills starting from working collaboratively, contributing to groups, conveying information clearly, communicating with each other, caring for all group members, responding to group needs and participating fully in various steps to solve problems.

Furthermore, students are invited to do Battle Games activities. The game is designed to be flexible, not bound by rules. The game is intended to provide fun activities for students even though they are studying online at home. The game is designed to give students the opportunity to interact with each other, either by using the WhatsApp, Google Meet or Zoom Meeting applications. This activity will foster motivation and enthusiasm for students in learning. Even though the learning activities are structured with exhausting activities, the end of the lesson is packed with fun activities which are an effort to make students interested in participating in further learning activities

The activity continued with the Unity on Role Play and Invent the Creation activity. This activity is filled with illustrating events related to subject matter that involve students as the main actors in it. The delivery of illustrations is carried out in the form of a story as well as provoking enthusiasm of students in practical activities through movements and words. The teacher prepares a scenario before the start of learning to clarify the learning material that will be delivered or given to student.

The teacher asks each group representative to come forward to get information on learning materials that will be delivered by the teacher. This activity will foster students' concern for the environment, because the role play content will focus on the skills to act on environmental issues and respond to environmental damage that occurs to feel how environmental conditions are from two sides. Thus students can weigh the best attitude to respect the environment. Role play activities can also train student collaboration, because role play activities contain collaborative work activities, contribute to groups, convey information clearly, communicate with each other, care for all group members, respond to group needs and fully participate in various steps of group activities. At the end of the lesson before the teacher gives an award.

\section{CONCLUSSION}

a. the characteristic and implementation of the blended learning model GAWI SABUMI consist of Group, Analysis, Work Together, Inform, Solve the problem on outdoor, Actualization of solution, Battle games, Unity on role play, Manage conclusion and Invent the creation; 
b. blended learning model GAWI SABUMI is appropriate to be used according to the results of the validation from 3 experts with validation percentage of learning steps get hich criteria, skills improvement get high criteria and teaching materials also get high criteria

c. blended learning model GAWI SABUMI is effective to be used in learning based on the results of evaluations using instruments of soft and social skills.

d. The improvement after implementation blended learning model, the students who are getting high criteria on ecological awareness, critical thinking, problem-solving, independence, collaboration, negotiation and communication from low criteria increase to high criteria more than $75 \%$

\section{REFERENCES}

[1] Hasratuddin, "Pembelajaran Matematika Sekarang dan yang akan Datang Berbasis Karakter," Didakt. Mat., vol. 1, no. 2, pp. 30-42, 2014, doi: 10.24815/jdm.v1i2.2059.

[2] E. Istianah, "Meningkatkan Kemampuan Berpikir Kritis Dan Kreatif Matematik Dengan Pendekatan Model Eliciting Activities (Meas) Pada Siswa Sma," Infin. J., vol. 2, no. 1, p. 43, 2013, doi: 10.22460/infinity.v2i1.23.

[3] Suparman and D. N. Husen, "PENINGKATAN KEMAMPUAN BERPIKIR KREATIF SISWA MELALUI PENERAPAN MODEL PROBLEM BASED LEARNING," J. ßIOêduKASI, vol. 3, no. 2, pp. 367-372, 2015.

[4] M. Tendrita, S. Mahanal, and S. Zubaidah, "Pemberdayaan Keterampilan Berpikir Kreatif melalui Model Remap Think Pair Share," Proceeding Biol. Educ. Conf. (ISSN 2528-5742), vol. 13, no. 1, pp. 285-291, 2016.

[5] A. Suriansyah and S. Mahriati, "Meningkatkan Hasil Belajar Konsep Sifat-Sifat Bangun Ruang dengan Model Pembelajaran Two Stay Two Stray dan Media Realia Siswa Kelas V SDN Pengambangan 8 Kota Banjarmasin," $J$. Paradig., vol. 11, no. 2, p. 118, 2016.

[6] A. R. Agusta, P. Setyosari, and C. Sa'dijah, "Implementasi Strategi Outdoor Learning Variasi Outbound untuk Meningkatkan Kreativitas dan Kerjasama Siswa Sekolah Dasar," J. Pendidik. Teor. Penelitian, dan Pengemb., vol. 3, no. 4, pp. 453-459, 2018.

[7] D. Zuchdi, Z. K. Prasetya, and D. M. S. Masruri, "Pengembangan Model Pendidikan Karakter Terintegrasi Dalam Pembelajaran Bidang Studi Di Sekolah Dasar," J. Cakrawala Pendidik., vol. 1, no. 3, pp. 1-12, 2010, doi: 10.21831/cp.v1i3.224.

[8] E. Widiasworo, Strategi \& Metode Mengajar
Siswa di Luar Kelas (OUTDOOR LEARNING) Secara Aktif, Kreatif, Inspiratif, \& Komunikatif. Yogyakarta: Ar-Ruzz Media, 2017.

[9] A. Z. Khusnia, N. A. YD, and M. Rahardjo, "Indeks Pencemaran Lingkungan Secara FisikaKimia dan Biokonsentrasi Timbal $(\mathrm{Pb})$ pada Kerang Hijau di Perairan Pesisir Semarang Utara," J. Presipitasi, vol. 16, no. 3, 2019.

[10] H. Yunansah and Y. T. Herlambang, "Pendidikan berbasis ekopedagogik dalam menumbuhkan kesadaran ekologis dan mengembangkan karakter siswa sekolah dasar," vol. 9, no. 1, pp. 27-34, 2017.

[11] R. Ennis, "Critical Thinking: Reflection and Perspective Part 1," Inq. Crit. Think. Across Discip., vol. 26, no. 1, 2011.

[12] Kowiyah, "Kemampuan Berpikir Kritis," $J$. Pendidik. Dasar2, vol. 3, no. 5, pp. 175-179, 12AD.

[13] R. Mahmuzah and M. Ikhsan, "Peningkatan Kemampuan Berpikir Kritis Dan Disposisi Matematis Siswa Smp Dengan Menggunakan Pendekatan Problem Posing," Didakt. Mat., vol. 1, no. 2, pp. 43-53, 2014, doi: 10.24815/dm.v1i2.2076.

[14] A. H. Panjaitan and E. Surya, "Creative Thinking (Berpikir Kreatif) Dalam Pembelajaran Matematika," 2017.

[15] Akhmad Riandy Agusta dan Noorhapizah, "Improving the Student 's Cooperation and Environmental Care Skill using Outdoor Learning Strategy Outbound Variation," $A d v$. Soc. Sci. Educ. Humanit. Res., vol. 274, pp. 10 17, 2018.

[16] M. A. Alwadai, "Islamic Teachers' Perceptions of Improving Critical Thinking Skills in Saudi Arabian Elementary Schools," J. Educ. Learn., vol. 3, no. 4, pp. 37-48, 2014, doi: 10.5539/jel.v3n4p37.

[17] Hamid Saremi \& Sosan Bahdari, "The Relationship between Critical Thinking with Emotional Intelligence and Creativity among Elementary School Principals in Bojnord City, Iran," Int. J. if Life Sci., vol. 9, no. 6, pp. 33-40, 2015.

[18] S. Putu, K. Surata, and J. S. Lansing, "Engaging Student Teachers in Designing Ecopedagogy Learning Modules for Bali' s Subak Culturan Landscape," NACTA J., pp. 139-143, 2015.

[19] R. M. Vieira and C. Tenreiro-vieira, "Fostering Scientific Literacy and Critical Thinking in Elementary Science Education," Int. J. Sci. Math. Educ., vol. 14, no. 4, pp. 659-680, 2016, doi: 10.1007/s10763-014-9605-2.

[20] Y. Fitria, F. N. Hasanah, and N. Gistituati, "Critical Thinking Skills of Prospective Elementary School Teachers in Integrated 
Science-Mathematics Lectures," J. Educ. Learn., vol. 12, no. 4, pp. 597-603, 2018, doi: 10.11591/edulearn.v12i4.9633.

[21] Y. Elfrida, Y. Siregar, R. Rachmadtullah, and N. Pohan, "The impacts of science, technology , engineering, and mathematics ( STEM ) on critical thinking in elementary school The impacts of science, technology, engineering, and mathematics ( STEM ) on critical thinking in elementary school," J. Phys. Conf. Ser., vol. 1175 , no. 1 , 2019, doi: $10.1088 / 1742-$ 6596/1175/1/012156.

[22] S. Butchart et al., "Improving critical thinking using web based argument mapping exercises with automated feedback," 270 Australas. J. Educ. Technol., vol. 25, no. 2, pp. 268-291, 2009.

[23] D. Djamas, V. Tinedi, and Yohandri, "Development of interactive multimedia learning materials for improving critical thinking skills," Int. J. Inf. Commun. Technol. Educ., vol. 14, no. 4, pp. 66-84, 2018, doi: 10.4018/IJICTE.2018100105.

[24] N. Cavus and H. Uzunboylu, "Improving critical thinking skills in mobile learning," vol. 1, pp. 434-438, 2009, doi: 10.1016/j.sbspro.2009.01.078.

[25] I. Novikasari, "Pengembangan Kemampuan Berpikir Kritis Siswa melalui Pembelajaran Matematika Open-ended di Sekolah Dasar," J. Pemikir. Altern. Kependidikan, vol. 14, no. 2, pp. 1-13, 2009.

[26] A. N. Rahma, "PENGEMBANGAN PERANGKAT PEMBELAJARAN MODEL INKUIRI BERPENDEKATAN SETS MATERI KELARUTAN DAN HASILKALI KELARUTAN UNTUK MENUMBUHKAN KETERAMPILAN BERPIKIR KRITIS DAN EMPATI SISWA TERHADAP LINGKUNGAN," J. Educ. Res. Eval., vol. 1, no. $2,2012$.

[27] A. W. Raula Samsul Amarila, Noor Aini Habibah, "PENGEMBANGAN ALAT EVALUASI KEMAMPUAN BERPIKIR KRITIS SISWA PADA PEMBELAJARAN IPA TERPADU MODEL WEBBED TEMA LINGKUNGAN," USEJ, vol. 3, no. 2, pp. 563569, 2014.

[28] R. R. M. Syutharidho, "Pengembangan Soal Berpikir Kritis untuk Siswa SMP Kelas VIII," Al-Jabar J. Pendidik. Mat., vol. 6, no. 2, pp. 219-227, 2015.

[29] K. H. S. Dwi Septiana Sari, "PENGEMBANGAN MULTIMEDIA BERBASIS MASALAH UNTUK MENINGKATKAN MOTIVASI BELAJAR DAN KEMAMPUAN BERPIKIR KRITIS
SISWA," J. Inov. Pendidik. IPA, vol. 1, no. 2, pp. 153-166, 2015.

[30] M. Firdaus and I. Wilujeng, "Pengembangan LKPD inkuiri terbimbing untuk meningkatkan keterampilan berpikir kritis dan hasil belajar peserta didik," J. Inov. Pendidik. IPA, vol. 4, no. 1, pp. 26-40, 2018.

[31] H. S. Tanjung and S. A. Nababan, "MATEMATIKA BERORIENTASI MODEL PEMBELAJARAN BERBASIS MASALAH ( PBM ) UNTUK MENINGKATKAN KEMAMPUAN BERPIKIR KRITIS SISWA SMA SE-KUALA NAGAN RAYA ACEH," Genta Mulia, vol. IX, no. 2, pp. 56-70, 2018.

[32] M. Caroselli, 50 Activities for Developing Critical Thinking Skills. London: HRD Press, 2009.

[33] S. Maričić and K. Špijunović, "Developing Critical Thinking in Elementary Mathematics Education through a Suitable Selection of Content and Overall Student Performance," Procedia - Soc. Behav. Sci., vol. 180, no. May, pp. 653-659, 2014, doi: 10.1016/j.sbspro.2015.02.174.

[34] Thompson, Crafting \& Executing Strategy; The Quest for Competitive Advantage (Sixteenth Edition). New York: Mc-Graw Hill International Editon, 2008.

[35] G. Gunantara, M. Suarjana, and P. N. Riastini, "PENERAPAN MODEL PEMBELAJARAN PROBLEM BASED LEARNING UNTUK MENINGKATKAN KEMAMPUAN PEMECAHAN MASALAH MATEMATIKA SISWA KELAS V," J. Mimb. PGSD Univ. Pendidik. Ganesha, vol. 2, no. 1, 2014, doi: 10.15294/kreano.v10i2.19671.

[36] E. Nurnawati, D. Yulianti, and H. Susanto, "PENINGKATAN KERJASAMA SISWA SMP MELALUI PENERAPAN PEMBELAJARAN KOOPERATIF PENDEKATAN THINK PAIR SHARE," UPEJ, vol. 1, no. 2257, 2012.

[37] Y. Y. Manafe, P. Setyosari, D. Kuswandi, and S. Ulfa, "Pengaruh Strategi Kerjasama Kelompok dan Efikasi Diri terhadap Hasil Belajar Keterampilan Teknikal," J. Pendidik. Hum., vol. 4, no. 3, pp. 152-162, 2016.

[38] G. Lord and L. Lomicka, "Blended learning in teacher education: An investigation of classroom community across media," Contemp. Issues Technol. Teach. Educ., vol. 8, no. 2, pp. 158-174, 2008.

[39] J. Bersin, The Blended Learning Book:, Best Practices, Proven Methodologies, and Lessons Learned. USA: Pfeiffer Publishing, 2004.

[40] A. Sutisna, "Pengembangan Model Pembelajaran Blended Learning pada 
Pendidikan Kesetaraan Program Paket C dalam Meningkatkan Kemandirian Belajar," J. Teknol. Pendidik., vol. 18, no. 3, pp. 156-168, 2016.

[41] Sugiyono, Metode Penelitian Kuantitatif Kualitatif dan R\&D. Bandung: Alfabeta, 2007.

[42] M. I. Thiagarajan, S., Semmel, D. S \& Semmel, Instructional Development for Training Teachers of Expectional Children. Minneapolis, Minnesota: Leardership Training Institure/Special Education, University of Minnesota, 1974.

[43] Iskandar, Metodologi Penelitian Kualitatif. Jakarta: Gaung Persada Press, 2009.

[44] N. Mahnun, "Media Pembelajaran (Kajian terhadap Langkah-langkah Pemilihan Media dan Implementasinya dalam Pembelajaran)," anNida', vol. 37, no. 1, pp. 27-35, 2012.

[45] A. Syahbana, "PENGEMBANGAN PERANGKAT PEMBELAJARAN BERBASIS KONTEKSTUAL UNTUK MENGUKUR KEMAMPUAN BERPIKIR KRITIS MATEMATIS SISWA SMP," Edumatica, vol. 02, no. 02, pp. 17-26, 2012.

[46] B. Hartati, "Pengembangan alat peraga gaya gesek untuk meningkatkan keterampilan berpikir kritis siswa sma," J. Pendidik. Fis. Indones., vol. 6, pp. 128-132, 2010.

[47] dan T. P. Savitri Herdianawati, Herlina Fitrihidajati, "PENGEMBANGAN LEMBAR KEGIATAN SISWA ( LKS ) INKUIRI BERBASIS BERPIKIR KRITIS PADA," BioEdu2, vol. 2, no. 1, pp. 99-104, 2013.

[48] D. M. M. and K. B. Wilson J. Warren, "Improving Critical Thinking Skills in the United States Survey Course: An Activity for Teaching the Vietnam War," Hist. Teacher, vol. 37, no. 2, pp. 193-209, 2004.

[49] M. Duran and İ. Dökme, "The effect of the inquiry-based learning approach on student' $\mathrm{s}$ critical -thinking," Eurasia J. Math. Sci. Technol. Educ., vol. 12, no. 12, pp. 2887-2908, 2016, doi: 10.12973/eurasia.2016.02311a.

[50] S. K. H. Shan Duta Sukma Pradana, Parno, "PENGEMBANGAN TES KEMAMPUAN BERPIKIR KRITIS PADA MATERI OPTIK GEOMETRI UNTUK MAHASISWA FISIKA," J. Penelit. dan Eval. Pendidik., vol. 21, no. 1, pp. 51-64, 2017.

[51] I. Selviani, "Pengembangan Modul Biologi Problem Based Learning Untuk Meningkatkan Kemampuan Berpikir Kritis Peserta Didik SMA," IJIS Edu Indones. J. Integr. Sci. Educ., vol. 1, no. 2, pp. 147-154, 2019.

[52] P. A. Weissinger, Enhancing Thinking through Problem-based Learning Approaches. Singapore: Thomson Learning, 2004.

[53] P. Dwijananti and D. Yulianti,
"PENGEMBANGAN KEMAMPUAN BERPIKIR KRITIS MAHASISWA MELALUI PEMBELAJARAN PROBLEM BASED INSTRUCTION PADA MATA KULIAH FISIKA LINGKUNGAN," J. Pendidik. Fis. Indones., vol. 6, pp. 108-114, 2010.

[54] S. Hasan, F. M. Tumbel, and A. Duran Corebima, "Empowering Critical Thinking Skills in Indonesia Archipelago: Study on Elementary School Students in Ternate," J. Mod. Educ. Rev., vol. 3, no. 11, pp. 2155-7993, 2013.

[55] J. C. Ricketts and R. D. Rudd, "Critical thinking skills of selected youth leaders: the efficacy of critical thinking dispositions, leadership, and academic performance," J. Agric. Educ., vol. 46, no. $1,2005$.

[56] J. R. Savery, "Overview of Problem-based Learning: Definitions and Distinctions," Interdiscip. J. Probl. Learn. Vol., vol. 1, no. 1, 2006.

[57] S. Sinprakob and N. Songkram, "A proposed model of problem-based learning on social media in cooperation with searching technique to enhance critical thinking of undergraduate students," Procedia - Soc. Behav. Sci., vol. 174, pp. 2027-2030, 2015, doi: 10.1016/j.sbspro.2015.01.871.

[58] S. Wahyuni, "Pengembangan Bahan Ajar IPA Untuk Meningkatkan Kemampuan Berpikir Kritis Siswa SMP," in Prosiding Seminar Nasional Fisika dan Pendidikan Fisika (SNFPF), 2015, vol. 6, no. 1, pp. 300-305.

[59] P. R. Nasution, E. Surya, and E. Syahputra, "Perbedaan Peningkatan Kemampuan Berpikir Kreatif Matematis dan Kemamdirian Belajar Siswa Pada Pembelajaran Berbasis Masalah dan Pembelajaran Konvensional di SMPN 4 Padangsidempuan," J. Parad., vol. 8, no. 3, pp. 38-57, 2015.

[60] B. Meyer, N. Haywood, D. Sachdev, and and S. Faraday, "What is independent learning and what are the benefits for students?" Departement for Children, Schools and Families Research Report, London, 2008.

[61] S. Rijal and S. Bachtiar, "Hubungan antara Sikap, Kemandirian Belajar, dan Gaya Belajar dengan Hasil Belajar Kognitif Siswa," $J$. Bioedukatika, vol. 3, no. 2, p. 15, 2015, doi: 10.26555/bioedukatika.v3i2.4149.

[62] A. Mulyana and U. Sumarmo, "Meningkatkan Kemampuan Penalaran Matematik dan Kemandirian Belajar Siswa SMP melalui Pembelajaran Berbasis Masalah,” Didaktik, vol. 9, no. 1, pp. 40-51, 2015.

[63] A. I. Rahmah, Sudiyanto, and D. Octoria, "PENGEMBANGAN BAHAN AJAR INTERAKTIF UNTUK MENINGKATKAN 
KEMANDIRIAN BELAJAR SISWA PADA PEMBELAJARAN AKUNTASI," Tata Arta, vol. 2, no. 1, pp. 73-83, 2016.

[64] J. Chau and G. Cheng, "Towards understanding the potential of e-portfolios for independent learning: A qualitative study," Australas. $J$. Educ. Technol., vol. 26, no. 7, pp. 932-950, 2010.

[65] R. Field, J. Duffy, and A. Huggins, "Teaching independent learning skills in the first year: A positive psychology strategy for promoting law student well-being," J. Learn. Des., vol. 8, no. 2, pp. 1-10, 2015.

[66] D. Wagener, "Promoting independent learning skills using video on digital language laboratories," Comput. Assist. Lang. Learn., vol. 19, no. 4-5, pp. 279-286, 2006, doi: $10.1080 / 09588220601043180$.

[67] E. Nurhayati, "Penerapan scaffolding untuk pencapaian kemandirian belajar siswa," $J$. Penelit. Pendidik. dan Pengajaran Mat., vol. 3, no. 1, pp. 21-26, 2017.

[68] I. W. Handayani, L., Nyoman, N., Dantes, N., \& Suastra, "Pengaruh Model Pembelajaran Mandiri terhadap Kemandirian Belajar dan Prestasi Belajar IPA Siswa Kelas VIII SMP N 3 Singaraja," Universitas Ganesha, 2013.

[69] M. Ibrahim and M. Nur, Pengajaran Berdasarkan Masalah. Surabaya: Unesa University Press, 2000.

[70] U. Sumarmo, "Kemandirian Belajar: Apa, Mengapa, dan Bagaimana Dikembangkan Pada Peserta Didik," 2006.

[71] U. Sumarmo, W. Hidayat, R. Zukarnaen, M. Hamidah, and R. Sariningsih, "KEMAMPUAN DAN DISPOSISI BERPIKIR LOGIS, KRITIS, DAN KREATIF MATEMATIK (Eksperimen terhadap Siswa SMA Menggunakan Pembelajaran Berbasis Masalah dan Strategi Think-Talk-Write)," J. Pengajaran Mat. dan Ilmu Pengetah. Alam, vol. 17, no. 1, p. 17, 2012, doi: 10.18269/jpmipa.v17i1.228.

[72] B. BsY, "Pengembangan Kemandirian Belajar Berbasis Nilai Untuk Meningkatkan Komunikasi Matematik," J. Pendidik. Mat. dan IPA, vol. 1, no. 1, pp. 11-22, 2010, doi: 10.26418/jpmipa.v1i1.148.

[73] M. Al Fatihah, "Hubungan Antara Kemandirian Kemandirian Belajar Belajar dengan dengan PAI Siswa Kelas III SDN Prestasi Belajar PAI Panularan Surakarta," At-Tarbawi J. Kaji. Kependidikan Islam, vol. 1, no. 1, pp. 1-12, 2016.

[74] R. Azka and R. H. Santoso, "Pengembangan Perangkat Pembelajaran Kalkulus Untuk Mencapai Ketuntasan dan Kemandirian Belajar Siswa," J. Ris. Pendidik. Mat., vol. 2, no. 1, pp.
78-91, 2015.

[75] M. E. Harrsion and and W. B. Whalley, "Combining student independent learning and peer advice to improve the quality of undergraduate dissertations," Planet, no. 16, 2006.

[76] M. Pokorny and H. Pokorny, "Widening participation in higher education: Student quantitative skills and independent learning as impediments to progression," Int. J. Math. Educ. Sci. Technol., vol. 36, no. 5, pp. 445-467, 2005, doi: $10.1080 / 00207390500062621$.

[77] G. Kadarisma, "Meningkatkan Kemandirian Belajar Siswa Smp Dalam Matematika Dengan Menggunakan Pendekatan Saintifik," Symmetry Pas. J. Res. Math. Learn. Educ., vol. I, pp. 6166, 2016, doi: 10.23969/symmetry.v1i1.214.

[78] I. Lestari, "Pengembangan Layanan Informasi Teknik Symbolic Model Dalam Membantu Mengembangkan Kemandirian Belajaranak Usia Sekolah Dasar," J. Konseling Gusjigang, vol. 1, no. 1, 2015, doi: 10.24176/jkg.v1i1.261.

[79] B. A.M and E. Rohaeti, "MENGEMBANGKAN KEMAMPUAN BERPIKIR KREATIF DAN KEMANDIRIAN BELAJAR SISWA SMA MELALUI PEMBELAJARAN BERBASIS MASALAH," J. Pengajaran MIPA, vol. 19, no. 2, pp. 166-172, 2014.

[80] K. Swandhana, M. Churiyah, and L. Juariyah, "Meningkatkan Kemandirian Belajar dan Hasil Belajar Siswa melalui Pengembangan Modul Administrasi Kepegawaian Berbasis Strategi Pembelajaran Inkuiri Terbimbing," J. Pendidik. Bisnis dan Manaj., vol. 2, no. 3, pp. 161-169, 2016.

[81] I. D. Pratiwi and H. Laksmiwati, "Kepercayaan Diri dan Kemandirian Belajar Pada Siswa SMA Negeri ' $X$ ' Iffa Dian Pratiwi, dan Hermien Laksmiwati Program Studi Psikologi Universitas Negeri Surabaya," J. Psikol. Teor. Terap., vol. 7, no. 1, pp. 43-49, 2016.

[82] N. Fahradina, B. I. Ansari, and Salman, "Peningkatan Kemampuan Komunikasi Matematis dan Kemandirian Belajar Siswa SMP dengan Menggunakan Model Investigasi Kelompok," J. Didakt. Mat., vol. 1, no. 1, pp. 303-323, 2014.

[83] E. Sutarno and Mukhidin, "Pengembangan Model Pembelajaran Berbasis Multimedia Interaktif Pengukuran Untuk Meningkatkan Hasil Dan Kemandirian Belajar Siswa SMP Di Kota Bandung," J. Pendidik. Teknol. dan Kejuru., vol. 21, no. 3, pp. 1-1, 2015, doi: 10.21831/jptk.v21i3.3258.

[84] W. D. Pramana and N. R. Dewi, "Pengembangan E-Book Ipa Terpadu Tema Suhu Dan Pengukuran Untuk Menumbuhkan 
Kemandirian Belajar Siswa," USEJ - Unnes Sci. Educ. J., vol. 3, no. 3, 2014, doi: 10.15294/usej.v3i3.4267.

[85] G. A. M. I M. Suarsana, "PENGEMBANGAN E-MODUL BERORIENTASI PEMECAHAN MASALAH UNTUK MENINGKATKAN KETERAMPILAN BERPIKIR KRITIS MAHASISWA," J. Pendidik. Indones., vol. 2, no. 2, pp. 264-275, 2013.

[86] M. L. Yeh and H. H. Chen, "Effects of an educational program with interactive videodisc systems in improving critical thinking dispositions for RN-BSN students in Taiwan," Int. J. Nurs. Stud., vol. 42, no. 3, pp. 333-340, 2005, doi: 10.1016/j.ijnurstu.2004.06.008.

[87] A. Facione, P., Measure reasons critical thinking: what it is and why it counts (rev. ed.). Millbrae, CA: Insight Assessment, 2011.

[88] M. F. C. P. Ningrum, Slameto, and E. Widyanti, "Upaya Meningkatkan Keterampilan Kerjasama Siswa pada Bidang Studi IPA Melalui Penerapan Model Group Investigation bagi Siswa Kelas 5 SDN Kumpulrejo 2," Wahana Kreat. Pendidik, vol. I, no. 3, pp. 7-13, 2018.

[89] A. Azis, D. Yulianti, L. Handayani, and P. B. Mengajar, "Penerapan Model Pembelajaran Kooperatif Dengan Memanfaatkan Alat Peraga Sains Fisika (Materi Tata Surya) Untuk Meningkatkan Hasil Belajar Dan Kerjasama Siswa," J. Pendidik. Fis. Indones., vol. 4, no. 2, pp. 94-99, 2006, doi: 10.15294/jpfi.v4i2.162.

[90] T. NA, "Meningkatkan Keterampilan Kerjasama Siswa Pada Tema Pengalamanku Menggunakan Model Pembelajaran Number Head Together (NHT)," J. Ilm. Wahana Pendidik., vol. 6, no. 2, 2020, doi: 10.5281/zenodo.3740939.

[91] S. Fauziyah and A. Hendriani, "PENINGKATAN KETERAMPILAN KERJASAMA MELALUI MODEL PEMBELAJARAN KOOPERATIF TEAMS GAMES TOURNAMENT KELAS III SEKOLAH DASAR," J. Pendidik. Guru Sekol. Dasar, vol. 4, no. 2, pp. 196-210, 2019. 